Старик В.А., канд. психол. наук

Київський національний торговельно-економічний університет

м. Київ, Україна https://scholar.google.com.ua/citations?user=JEYQNPAAAAAJ\&hl=uk

\title{
РОЗВИТОК ГАЛУЗЕЙ ПСИХОЛОГІЇ В УКРАЇНІ: ІМПЛЕМЕНТАЦІЯ ЄВРОПЕЙСЬКОГО ДОСВІДУ
}

Бурхливий розвиток психології у відповідь на зростаючий інтерес до особистості, групи, суспільства в цілому, що викликаний потребами соціальної практики, сприяв тому, що сьогодні психологія, залишаючись єдиною наукою, включає в себе близько 100 окремих галузей. Проте деякі галузі розвиваються випереджальними темпами у порівнянні 3 іншими. Серед них: психологія освіти, економічна психологія, організаційна психологія, юридична психологія, психологія діяльності в особливих умовах, військова психологія, а також медична психологія та психологія спорту.

Сучасна освіта в першу чергу зазнає глобальних перетворень, що викликані новими типами соціальних зв'язків, орієнтованих, у першу чергу, на глобалізацію взаємовідносин з іншими та самостійному пошуку інформації. Саме тому, створення педагогічно доцільного і психологічно безпечного освітнього середовища для навчання вимагає гнучкості, толерантності до нових завдань, високого рівня розвитку адаптивності, вміння визначати пріоритети та проявляти розумову і пошукову активність.

Питання методології дитячої та вікової психології досліджуються у роботах Г.О. Балла, І.Д. Беха, С.Д. Максименка, В.А. Роменця, В.О. Татенка, Н.В. Чепелєвої та ін. Проблеми розвитку творчості дитини знайшли вирішення у дослідженнях В.О. Моляко, Р.С. Пономарьової, В.А.Роменця. Розвиток особистості у підлітковому та юнацькому віці виступає предметом досліджень М.І.Алексєєвої, М.Й. Боришевського, В.О. Татенка, Н.В. Чепелєвої та ін. [1].

Економічні та соціальні зміни, що відбуваються наразі в Україні, визначають основні вектори економічної психології. Це відбувається, 
насамперед, завдяки розробкам наукових співробітників Інституту психології ім. Г.С. Костюка НАПН України. Інтенсивний розвиток економічної психології як окремої галузі психологічної науки забезпечується такими представниками цієї наукової школи, як: С.О. Жиляєва, О.В. Креденцер, В.І. Логодзінська О.А. Філь, О.Г. Ходакевич, Н.Ю. Худякова та ін.. Актуальні проблеми економічної психології також досліджуються вченими-психологами, такими як О.К. Любчук (м. Донецьк), Ю.Ф. Пачковський (м. Львів), Н.А. Побірченко (м. Київ), Н.В. Хазратова (м. Київ), Ю.М. Швалб (м. Київ) [1].

Наступною не менш важливою галуззю виступає юридична психологія, що на сучасному етапі розвитку науки є самостійною, цілісною галуззю та включає в себе правову, кримінальну, судову та пенітенціарну практично-прикладні гілки.

Наукове підгрунтя юридичної психології закладене в останній чветрі ХХ ст. роботами В.Г. Гончаренка, А.Ф. Зелінського, В.О. Коновалової, М.В. Костицького, О.П. Сєверова, В.М. Синьова. Сучасні актуальні теоретико-прикладні дослідження юридичної психології базуються на роботах О.М. Бандурки, В.І. Барко, С.П. Бочарової, О.В. Землянської, Л.І. Казміренка, 3.Р. Кисіля, В.О. Лефтєрова, В.С. Медведєва, С.І. Яковенка [2].

Ще однією галуззю психологічної науки, розвиток якої зумовлений запитами соціальної практики, виступає психологія діяльності в особливих умовах (космічна, авіаційна, військова психологія). Проте, соціально-політична ситуація останніх років в України докорінно порушує почуття безпеки індивіда, викликаючи у нього переживання травматичного стресу. Останнім часом військова та екстремальна психологія активно вивчає проблеми негативних психічних станів та відстрочених реакцій, що спостерігаються внаслідок пережитої психотравми. Дані проблемі досліджують такі вчені як Г.О. Балл, М.Д. Левітов, Ю.О. Олександровський, Ю.М. Швалб, у тому числі серед фахівців екстремальних професій - М.С. Корольчук, І.О. Котенєв, В.С. Медведєв, С.М. Миронець, Н.В. Оніщенко, О.М. Столяренко, О.В. Тімченко та інші [3].

Отже, перспективний розвиток галузей психології в Україні та відповідно якість освітньої підготовки майбутніх фахівців-психологів визначається актуальними потребами соціального замовлення. 


\section{Список бібліографічних посилань}

1. Психологія управління : навч. посіб. / Л.М. Карамушка. - Київ : Міленіум, 2003. - 344 с.

2. Юридична психологія : підручник / С.Д. Максименко, В.С. Медведєв. - Київ : Слово, 2018. - 448 с.

3. Психологічні наслідки перебування рятувальників у зоні проведення антитерористичної операції : монографія / С.Ю. Лєбєдєва, О.О. Назаров, Я.О. Овсяннікова та / за заг. ред. Н.В. Оніщенко, О.В. Тімченка. - Харків : НУЦЗУ, 2019. - 174 с. 